2. Туровська Л. В. До проблеми періодизації розвитку української військової термінології: зб. наук. праць. К., 2003. Вип. V. С. 83-90.

3. Яценко Н. О. Формування назв військового одягу в українській мові: монографія. К.: Вид-во «Дім Бураго», 2009. 180 с.

4. Михайленко Т. Д. Інтра- і екстралінгвістичні аспекти формування і функціонування військової терміносистеми в національних мовах (на матеріалі російської, німецької та української мов): автореф. дис. ... докт. філол. наук: спец. 10.02.15 «Загальне мовознавство». М., 1996. 48 с.

5. Симоненко Л.О. Українська термінологія: стан, проблеми i перспективи 1993. 18 березня.

6. Огієнко I. І. Інститут Української Наукової Мови в Києві. Рідна мова. 1933. Ч. IV. С. 118.

DOI https://doi.org/10.30525/978-9934-588-90-7-51

\title{
ФЕНОМЕН КОНЦЕПТУ «СМІХ» У ФОРМУВАННІ СОЦІОКУЛЬТУРНОГО ПРОСТОРУ
}

\section{Варварук I. B.}

кандидатка філологічних наук, доиентка кафедри перекладу та філології

Приватний вищий навчальний заклад Університет Короля Данила м. Івано-Франківськ, Украӥна

Проблема сміху була в центрі наукових зацікавлень багатьох дослідників: філософів - Аристотеля, А. Бергсона, Г.В.Ф. Гегеля, I. Канта, А. Шопенгауера， З. Фрейда; культурологів - М. Бахтіна, Л. Карасьова, Д. Лихачова; мовознавців - Н. Зарубіної, Ю. Кузнєцова, Л. Панкової, В. Кононенка, В. Ганєчко, Л. Мацько та інших.

Однак, дослідження концепту “сміх” як надбання людської діяльності, у якій ключове значення мають досвід та результати пізнання світу носіями мови, повинно доповнюватися знаннями інших дисциплін, зокрема філософії, психології, культурології, естетики. У зв’язку з цим розглянемо передумови осмислення сміху як мовного феномену, важливого лінгвокультурного концепту, його ролі у формуванні сміхової культури сучасного суспільства, що, власне, зумовлює актуальність дослідження.

На сучасному етапі розвитку суспільства вчені розглядають концепт “сміх” різнобічно. Так, М. Рюміна у книзі “Естетика сміху” розглядає сміх у ключі філософсько-естетичних категорій як "прикордонний стан між 
природою та культурою" [7, с. 146]. При цьому дослідниця зауважує: культурний сміх "має" психофізіологічну основу з надбудованими на ній культурно виробленими смислами. Розглядаючи першим архаїчний ритуальний сміх порівняно 3 культурним сміхом, учена говорить про перетворення сміху, що актуалізувало “смисли, протилежні його природному “радісному” значенню" [7, с. 130].

Дещо інше осмислення цього явища подає Л. Карасьов, детермінуючи сміх як культурно-психологічний феномен, у якому виражається здатність людини виявляти життєві комічні ситуації. Він $є$ сплавом “емоційних і раціональних моментів. Далі дослідник говорить про двозначність сміху, виокремлюючи "сміх тіла" (антитеза - плач), що виражає радість та ентузіазм здорового тіла, яке росте в насолоді, i “сміх розуму” (антитеза сором) - власне людський чи “комічний” сміх [4, с. 32-33].

Досліджуючи концепцію смішного, А. Шопенгауер зазначає: “сміх завжди виникає ні 3 чого іншого, як із несподіваного пізнання “незбігання" між відомими поняттями і реальними об'єктами, які в будьякому відношенні мислилися у цьому понятті [9, с. 61]”. Як і Л. Карасьов, філософ виокремлює два "роди” смішного: “смішне $y$ думиі - "гостроту, для якої характерним є перехід від реального об'єкта до поняття", та “смішне у вчинку" - “безглуздість", при якій акцент зроблено на переході від поняття до реального [9, с. 64.]

Концепція смішного стала предметом наукових осмислень I. Канта. Незважаючи на те, що поняття комічного було на периферії його досліджень, думки вченого, присвячені сміху, відіграли важливу роль у становленні категорії комічного. Так, філософ подає таке тлумачення сміху: "У всьому, що викликає веселий, нестримний сміх, повинно бути щось безглузде. Сміх - це афект від раптового напруженого очікування у ніщо. Саме це перевтілення, яке для розуму є явним, все ж побічно викликає на мить радість" [3, с. 207]. Отож, психофізіологічний чинник, на думку I. Канта, є двигуном виникнення сміху, і саме "тілесний рух" (“сміх тіла" та “смішне у вчинку") є джерелом задоволення, конструктивних емоцій. Така концепція знайшла підтримку в дослідженнях А. Бергсона, Л. Карасьова, 3. Фрейда тощо.

Неоднозначна природа досліджуваного феномена ставала предметом вивчення багатьох науковців. Так, М. Бахтін "силою сміху" вважає якраз його амбівалентність, яка "несе в собі особливе смислове співвідношення культури сміху із світоглядними орієнтаціями добра $і$ зла" [1, с. 16]. Він $\epsilon$ тим феноменом, який “породжує безліч гіпотез $і$ ламає звичний хід речей, з'єднуючи непоєднуване” [1, с. 11-13]. Такий погляд сприяв виникненню в науковій літературі “бахтінськоі” концепції сміху, суть якої полягає у 
тому, що "сміх передбачає подолання страху; не існує заборон і обмежень, створених сміхом; влада, насилля, авторитет ніколи “не говорять" мовою сміху" [1, с. 54]. Підкреслимо, що М. Бахтін - один із перших дослідників, який розглядав сміх крізь призму культурної специфіки. У руслі, задекларованому у його вченнях, працювали й інші науковці, зокрема Д. Лихачов, М. Хрєнов та інші.

Особливе зацікавлення викликає підхід М. Хрєнова, за яким сміх, його роль та функції розглядаються в контексті культури перехідних епох. Як зазначає вчений, “сміх є одночасно вираженням свободи, навіть хаосу, $i$ в той же час-фактором становлення нової системи цінностей” [8, с. 328]. Близькою до сказаного є думка В. Проппа про те, що в період змін "комічним може стати те, щзо безповоротно відійшло у минуле $i$ не відповідає нормам, створеним загальними настроями" [6, с. 53].

Як бачимо, більшість науковців розглядають сміх як культурний феномен, у якому виражається здатність людини комічно оцінювати дійсність і який (поряд із думкою та мовою) відрізняє людину від тварини. Крім цього, сміх визначається дослідниками ще й як “відхилення" від певної норми (ситуації, явища, людини). Тому, вважаємо, формується думка про амбівалентну (двосмислову) природу сміху. Очевидно, цей факт і $\epsilon$ джерелом актуалізації креативних смислів концепту “сміх", які прочитуємо в текстах сучасного художнього дискурсу.

Широке зацікавлення психологів, філософів, лінгвістів проблемами дослідження комічного (смішного) сприяло визначенню сміху і як наукової категорії, яка достатньо широко вивчалася вченими в різних аспектах. На сучасному етапі розвитку культури терміном, який позначає науку про сміх, є гелологія, або сміхологія - вивчення сміху як фізикобіологічного явища та феномену культури. Фундаторами нової науки $\epsilon$ М. Джервез та Д. Уілсон - дослідники Бірмінгемського університету (Англія), які вважають, що сміх є першим зародком мови ${ }^{1}$. Цю думку підтримали й розвинули вчені Санкт-Петербурзького державного університету, зокрема С. Троӥиький зазначає: “Сміх давно є предметом вивчення. 3 античності до нас дійшли тексти, в яких є пасажі, присвячені теоретичному аналізу сміху. Накопичено багато знань у різних галузях науки, однак аж до нашого часу теорія сміху не отримала завершеного характеру",.

${ }^{1}$ Подано за матеріалами видань "New Scientist" (Англія) і "Decouverte” (Франція). Режим доступу: http://www.nkj.ru/archive/articles/13581.

2 Цитата подана 3 інтерв'ю видання ИА REGNUM, присвяченого конференції “Теоретическое исследование смеха в России и перспективы гелологии”, яка відбулася 
Отже, сміх як явище передусім культурне, має свою специфіку і реалізується через такі поняття: “сміховий світ” (Ю. Волков, В. Полікарпов), “сміхова культура" (Д. Лихачов, А. Панченко), “народна сміхова культура" (М. Бахтін), культура та субкультура сміху [цит. за: 5, с. 178].

Сміхова культура є тим феноменом, для якого характерна цілісність та універсальність культурних смислів. Виокремлюючи поняття "культури" (за А. Кребером) - виняткового продукту життєдіяльності людей, дослідниця Л. Баліна розглядає сміхову культуру як "ідентифікуючу особливість людини в космосі - Hoто ridens (“Людини, яка сміється" (Человека смеющегося”)), яка підкреслюе “надсоматичну / надбіологічну сутність людини" [2, с. 11] - сміятися.

Поняття "народна сміхова культура" $є$ перехідною ланкою між “сміховим світом" і “сміховою культурою”, особливостями якої $\epsilon$ природність, синкретичність, нормативність, відносна статичність, а найголовніше - традиційність [2, с. 166].

Окремі науковці, зокрема О. Кожем'якіна, послуговуються у своїх працях терміном “субкультура сміху", розуміючи під ним “сміхові переваги та особливості представників різних соціальних груп, які, взаємодіючи, формують загальну культуру сміху" [5, с. 179].

Так, крізь призму культури сміху “досліджуваний феномен розглядається 3 погляду здатності регулювати сміховий процес, що торкається сфери як ірраціонального, так і раціонального, свободи i обмеження, спонтанності і контролю, що є доволі складним процесом, оскільки сміх, по суті, пов'язаний із модусом свободи та відкритості” [5, c. 182].

Отже, сміх як важливий “універсал” людського буття нерозривно пов'язаний 3 культурою, особливостями ï формування, естетичною специфікою. Належність його до ряду історично вироблених i регламентованих форм суспільства, які представляють свої орієнтири світобачення та культурні цінності дає підстави для виокремлення особливої сміхової культури як частини загальнолюдської культури, яка розглядає дійсність крізь призму сміху та комічного.

\section{Література:}

1. Бахтин М. М. Эстетика словесного творчества. Москва: Искуство, 1979. $445 \mathrm{c}$.

10 червня 2011 року у Санкт-Петербурзькому державному університеті.- Режим доступу: http://mir24.tv/news/Science/4001438.

190 
2. Волков Ю. Г., Поликарпов В. С. Человек как космопланетарный феномен. Ростов-на-Дону: Издательство Ростовского университета, 1993. $192 \mathrm{c}$.

3. Кант И. Критика способности суждения. Киев: Азбука, 2019. 448 с.

4. Карасев Л. В. Философия смеха. Москва: Рос. гуманит. ун-т, 1996. $224 \mathrm{c}$.

5. Кожемякина О. Н. Доверие смеху в контексте современной трактовки проблемы культуры смеха. Studia Culture, 2011. Вып. 12. C. $176-183$.

6. Пропп В. Я. Роблемы комизма и смеха. Москва: Лабиринт, 2002. $192 \mathrm{c}$.

7. Рюміна М. Т. Эстетика смеха. Смех как виртуальная реальность. Изд. 3-е. Москва : Книжный дом «Либроком», 2010. 320 с.

8. Хренов Н. А. Введение. Эстетика и теория искуства XX века: альтернативные типы дискурсивности в контексте трансформации культуры. Эстетика и теория искуства XX века. Москва: ПрогрессТрадиция, 2008. С. 7-84.

9. Шопенгауер А. Полное собрание сочинений в 6 томах. Харьков: Книжный клуб «Терра», 1999-2001. 864 с.

DOI https://doi.org/10.30525/978-9934-588-90-7-52

\section{PATTERNS OF SEMANTIC VARIATION IN PHRASEOLOGY}

\section{Kozlova T. O.}

Doctor of Philological Sciences, Associate Professor, Professor at the English Philology Department Zaporizhzhia National University

Polyezhayev Yu. G.

Candidate of Sciences in Social Communications, Associate Professor, Associate Professor at the Department of Foreign Languages for

Professional Communication "Zaporizhzhia Polytechnic" National University

Zaporizhzhia, Ukraine

Introduction. Interest in the studies of phraseology has been steadily growing over the past fifty years. Theoretical and practical concerns go beyond the discussion of the issues related to the definition and typology of set 